Dušan Gabrovšek

University of Ljubljana, Slovenia
2020, Vol. 17 (2), 47-59(284)

revije.ff.uni-lj.si/elope

https://doi.org/10.4312/elope.17.2.47-59

UDC: $811.111^{\prime} 271=163: 81^{\prime} 374$

\title{
The Bilingual Usage Dictionary
}

\begin{abstract}
The paper highlights the dictionary of English usage as a type of specialized language dictionary. Such dictionaries have been created in either the time-honored prescriptivist tradition or the more recent descriptivist one. Virtually all dictionaries of English usage are monolingual, i.e. all-English. While most dictionaries of English usage have been designed for native speakers of English, there are also a few notable works made particularly for non-native speakers of the language. The main part of the paper is devoted to the suggestion and formulation of guidelines for creating a bilingual, specifically English/Slovene encoding-oriented usage dictionary as a useful, reliable, varied, and user-friendly work of reference intended primarily for advanced-level Slovene speakers of English. The dictionary offers some features that are uncommon in today's dictionaries, especially the use of both languages in many entries, and some entries challenging the user to find the solution to the language problem listed for themselves. The final section presents 20 selected entries from the envisioned usage dictionary.
\end{abstract}

Keywords: English usage, dictionary of usage, monolingual vs. bilingual, English/Slovene usage dictionary

\section{Dvojezični slovar jezikovne rabe}

\section{POVZETEK}

Prispevek obravnava slovar angleške jezikovne rabe kot vrsto specializiranega jezikovnega slovarja. Tovrstni slovarji nastajajo v okviru starejše predpisovalne tradicije ali pa novejše opisovalne tradicije. Praktično vsi slovarji angleške jezikovne rabe so enojezični, v celoti pisani v angleščini. Večina tovrstnih slovarjev je namenjena maternim govorcem angleškega jezika, vendar pa je nekaj znanih del namenjenih predvsem uporabnikom angleščine kot nematernega jezika. Glavni del pričujočega prispevka poda predlog in navaja smernice za izdelavo koristnega, zanesljivega, raznolikega in uporabniško prijaznega dvojezičnega, specifičneje angleško/slovenskega, slovarja predvsem za uvezovalne potrebe, ki bo namenjen v prvi vrsti Slovencem, ki uporabljajo angleščino na višji zahtevnostni ravni. Slovar uvaja nekatere značilnosti, ki jih v sodobnih slovarjih skoraj ni najti, zlasti uporabo obeh jezikov v številnih geslih in gesla, ki uporabnike vzpodbujajo, naj najdejo določeno rešitev za navedeni jezikovni problem kar sami. V zadnjem delu je predstavljenih 20 izbranih gesel iz predlaganega slovarja.

Ključne besede: angleška jezikovna raba, slovar jezikovne rabe, enojezični v. dvojezični, angleško/slovenski slovar jezikovne rabe 


\section{Introduction: Usage in Language and English Usage Dictionaries}

Usage, in the sense relevant to this paper, is "[ $t]$ he way a particular word in a language, or a language in general, is used" (McIntosh 2013, 1730). Importantly, "the term usage is a broader one than grammar, and is more judgmental" (Allen 2009, 339).

English usage has been recorded extensively in both general and specialized dictionaries. ${ }^{1}$ There are two competing and powerful general traditions in recording and analyzing language facts in general and language usage in particular, viz. the long-standing prescriptive one, epitomized in the magisterial Fowler guide, first published in 1926, and the more recent descriptive one. The former tradition typically lays down subjective rules regarded by an individual or group as "educated", "right", useful, recommended, etc., such normative rules "setting out a norm, i.e. what users of a language should say or write according to some ideology rather than a rule describing what users actually say or write", "an example [being] the rule that different is followed by from and not to." (Brown and Miller 2013, 314). The descriptive tradition, by contrast, provides an objective description and unbiased interpretation of language facts based on factual evidence (as in, say, Gilman 1989). Both linguists and dictionary makers of today almost invariably insist right at the outset on embracing the descriptive approach: As a matter of principle, according to most of them, it makes a lot of sense to point out that language simply must be described rather than being prescribed. However, many language users are often at odds with language professionals because what they typically seek is sound advice and reliable guidance. Indeed, as Aarts, Chalker and Weiner $(2014,429)$ have pointed out, "in practice, usage guides deal cursorily with consensual core grammar, and pay most attention to areas of disputed usage, giving guidance that veers towards prescription (which is doubtless what most users of such books want)". This implies that while it may well be a desideratum to try to draw on both prescriptive and descriptive approaches in creating a dictionary of usage, this may be exceedingly difficult to achieve. The two traditions, however, are not really incompatible - after all, the American lawyer, usage expert and prolific lexicographer Bryan A. Garner (in Garner and Greene 2012), one of the best-known usage authors, refers to himself as a usage author acting as a "descriptive prescriber". The prescriptive descriptive dilemma has been a major issue especially in native-speaker-oriented usage dictionaries of English. In any case, what a bilingual usage dictionary must set out to do is to give both sound advice and guidance and to offer solutions to a variety of language difficulties encountered in an interlingual framework by a non-native user of English as an L2. Can this be achieved entirely without, well, "enlightened prescription"?

First, a terminological note. What is commonly referred to as a usage dictionary or a dictionary of usage is basically a type of specialized language dictionary (such as those of, say, idioms, collocations, pronunciation, or etymology) as contrasted with both the general dictionary and the specialized field dictionary (of chemistry, music, psychology, linguistics etc.). However, there are also certain general dictionaries of the English language, whether monolingual or bilingual, that highlight the word usage in their titles typically either to indicate that the dictionary in question is a learners' one (e.g. Schwarz and Seaton 1985) or to emphasize

\footnotetext{
Books on English usage can also be divided into chapters rather than being arranged alphabetically (Allen 2009, 341). This paper is devoted exclusively to "those arranged in an alphabetical sequence of entries like a conventional dictionary" (Allen 2009, 341).
} 
that it does its best to show how a language or languages - particularly the core vocabulary - is/are actually used, usually by means of ample exemplification provided in the form of example sentences (e.g. Stein 2013). In this paper, usage dictionary consistently refers to a specialized language dictionary, also referred to as a usage guide, and this is "a type of reference work intended to help users with encoding tasks such as speaking or writing. Entries are often mini-essays on (unresolved) issues rather than articles on particular words or phrases." (Hartmann and Stork 1998, 149-50). What its entries characteristically offer is advice on grammar, vocabulary, spelling and hyphenation, as well as on stress and regional usage.

Again, when it comes to recording facts about usage for reference purposes, English usage is amply documented in both general and specialized dictionaries. While the coverage of usage in the former, "general-dictionary" mode dominates both monolingual (all-English) and bilingual dictionaries, the latter, "specialized-dictionary mode" - the one this paper concentrates on - is heavily favored when it comes to monolingual (i.e. all-English) dictionaries. The latter tradition, that is, monolingual (all-English) specialized dictionaries of English usage, some of which are (also) available for online consultation, ${ }^{2}$ comprises two distinct subtypes:

(a) the long-standing native-speaker-oriented variety epitomized - for British English in the famous Fowler (1926) guide, now is its fourth edition (Butterfield 2015), and for American English - in several Garner guides (cf. e.g. Garner 2016), and

(b) the learner-oriented variety (notably Swan [1980] 2016 and Sinclair 1992 / Hands 2019), which is of much more recent vintage and incorporates far fewer works than the native-speaker-oriented variety.

While both are monolingual, the two subtypes of specialized dictionaries of English usage just referred to are cast in rather different frameworks. The older, native-speaker-oriented tradition defines the concept in the following manner (Algeo 1991, 2-3): "Usage is a choice among alternatives to which users attribute social value." The three factors - alternatives, choice, and value - are related implicationally. To have value, there must be choice, and to have choice there must be alternatives; but alternatives may exist without choice, and choice without value. In this context, usage has the important dichotomy of use vs. attitude: To understand usage, we must be aware of both what people say and what they think about what is said. There are often striking disparities between the two (Algeo 1991, 2-3). Indeed, nativespeaker-type language use often embraces the significant sociolinguistic aspect of attitudes to language use, often referred to as usage. Significantly, "an attitude is an evaluative orientation to a social object [here language] of some sort" (Garrett 2010, 228). That is why nativespeaker-oriented dictionaries of English usage - unlike the learner-oriented ones - often discuss instances of disputed usage, a major concept defined as

a disagreement over what is the 'correct' linguistic form to use in a particular situation. Disputed usages, and the emotional and impassioned debates they inspire, are a

The best-known example is probably the native-speaker-type American usage dictionary by Paul Brians ([2004] 2013) that incorporates an introductory question-and-answer section, an otherwise uncommon feature in dictionaries of usage. This work can be either obtained in book form or accessed online. 
relatively recent phenomenon in the history of the English language, dating back only as far as the eighteenth century. (Meyer 1993, 302)

By contrast, dictionaries of English usage designed for (foreign) learners typically concentrate their efforts on helping users overcome English language problems; in a nutshell, in this particular framework (Swan [1980] 2016, viii), "Usage guides deal with problem points: words and structures that people have difficulty with [...]. English, like all languages, is full of problems for the foreign learner." The purpose of learner-oriented English usage dictionaries "is practical: to give learners and their teachers the most important information they need in order to deal with common language problems" (Swan [1980] 2016, viii).

The basic difference between the two subtypes of English usage dictionaries, then, is not only quite clear but also significant: It can be summarized as that between evaluative social-valuebased language choice offered by and underlying the native-speaker-type usage dictionaries on the one hand, and language difficulty and/or uncertainty in using language, especially a non-first one, underlying the learners' variety of usage dictionaries on the other.

\section{The Bilingual - Slovene-English - Usage Dictionary}

\subsection{General Principles}

Curiously enough, the bilingual mode in recording English usage in specialized reference sources is close to being non-existent. This paper thus argues for the creation of a specialized bilingual, specifically Slovene/English, dictionary of usage, English having the role of a foreign/non-first language, i.e. L2, Slovene typically being the user's L1. Accordingly, in what follows, Slovene (as L1) and English (as L2) will be used consistently for (illustrative) contrastive purposes.

The suggested usage dictionary is first and foremost an encoding-oriented reference tool focusing on the specific language pair, but also one providing selected decoding-oriented pieces of information, designed chiefly for the advanced learner of English. In general terms, it is based on the idea of teaching a foreign/non-first/second language, educating, translating into a foreign language, i.e. providing valuable interlingual information for translation purposes that illustrates, as its major underlying principle, the application of two interrelated subtypes of an approach to language analysis that can both be referred to broadly as the "nonmonolingual" approach, viz.

(a) The bilingual approach, i.e. that of specific contrastivity (individual points relating to specific issues in the two languages, e.g. collocation and false friends, such as SI imeti [EN have] predavanje - to give a lecture, or kubinjski aparat-kitchen appliance, gasilni aparat - fire extinguisher, shusni aparat - hearing aid, TV aparat - TV set) and

(b) The EFL approach, i.e. that of non-specific contrastivity (EFL-type general issues such as English confusables, for instance compliment - complement, exhaustive exhausting, and countability, for instance advice, information etc.). 
Of the two approaches, the latter is exemplified in the EFL-oriented dictionaries of English usage, the best-known examples probably being Swan ([1980] 2016) and Sinclair (1992) / Hands (2019). At least in the initial stage of writing a bilingual dictionary of usage, these reference sources are to be preferred over the more specialized, removal-of-errors-type of EFLoriented usage dictionaries, such as Trask (2001) or Turton and Heaton (1996), as well as over the reference sources that form part of the rich tradition of social-value-based-preference native-speaker-oriented dictionaries of English usage, such as Fowler (1926) / Butterfield (2015), Partridge ([1942] 1999) or Garner (2016). The former mode, i.e. bilingual, is far more difficult to capture comprehensively, as there is no systematic coverage, for most language pairs, of either specific contrastive topics relating to two specific languages or problematic issues collected expressly for the benefit of speakers of one of the two languages in question. The bilingual mode, overall, reflects an educational, language-teaching, and translationfriendly attitude. The selection of items/issues in the A-Z-format is to be based on the best and most reliable existing empirical studies and research, both traditional and corpus-based, as well as translators' notes and ideas, and on teaching experience gained in the bilingual, chiefly L1/L2 environment.

Entries in the suggested bilingual Slovene-English usage dictionary are based on the following two uncommon lexicographic principles:

(a) both languages - sometimes even combined in some way in one and the same entry-article - are to be used not only in the entry-articles (microstructure) but even as main entries and entry words (macrostructure). The reason for combining the two languages is to encourage comprehension, efficiency, interaction, one's own (dictionary) (re)search, and to maintain a user-friendly encoding stance.

(b) selected - especially shorter - entries do not provide solutions but only hint at them or even leave them out altogether, with some entries being framed as questions encouraging or challenging the user to look for and find solutions themselves, especially in a dictionary. Indeed, after stating the problem, some entries do not spell it out but only provide a standard English dictionary ${ }^{3}$ URL, and sometimes a link to a specific entry, as the suggested source to help one deal with a language issue (e.g. besides/beside below, comic/comical, and deciding/decisive). While only used sparingly, this technique ${ }^{4}$ (unusual, to be sure) of writing dictionary entries builds on the idea that certain - especially very common and specific as well as unexpected - contrastive language problems may goad the user into making an extra effort to find the solutions themselves.

Additionally, another two underlying principles must also be mentioned, the first being rather unconventional and the second less so:

Particularly those of the advanced learners' type, for instance Longman Dictionary of Contemporary English or MerriamWebster Learner's Dictionary, both listed in the References section.

In a later edition, URLs and links listed might be expanded to include, for example, selected links to specific language points provided in specialized online reference sources such as dictionaries of English usage (e.g. Brians [2004] 2013) and guides to punctuation (e.g. Punctuation Guide). The device should not be overdone, however, as its role is simply to provide varied access to specific language problems. 
(c) entries in the suggested dictionary will be diverse, extremely varied in terms of both content and overall length and complexity: very broad/general and encyclopedic, rather general, specific, highly specific, long and short, some of them being framed as questions or warnings, and varied in microstructure, including a small selection of basic linguistic topic entries such as stevnost [EN countability] and sopojavljanke (kolokacije) [EN collocations]. Exemplification - typically in the form of translated examples of language use, SL-EN and EN-SL, both sentence-length and phraselength - will be abundant as a matter of principle.

(d) abbreviations are to be used sparingly, and to be given chiefly in Slovenian.

\subsection{Broader Issues}

Given that it is bound to be primarily an online work with a functional search engine, the suggested bilingual English/Slovene dictionary of usage would be firmly based on the continuous-revision policy, and possibly crowd-sourced, drawing first and foremost on two categories of language/teaching professionals - translators and foreign language teachers and specifically on what they can contribute from their own work experience. As to the approaches to analyzing language contrastively, the work under discussion seeks pertinent answers by applying the insights of the classical contrastive analysis (James 1980), contrastive interlanguage analysis (cf. Granger 2015) and a variety of relevant methods based primarily on functional and cognitive linguistic theories (cf. the survey-type Gómez González, Mackenzie and González Álvarez 2008).

\subsection{Basic Entry Types Explained and Illustrated}

Below is a small selection of the different kinds of entries illustrating their significant features, to be considered for inclusion in such a bilingual Slovene/English usage dictionary. There are two basic kinds of entries:

(1) those discussing individual points, including both

[a] non-specific-contrastivity type of issues such as confusables, e.g. lie, lay; complement, compliment; bear, bare, and countability, e.g. information, evidence, advice and

[b] (language-)specific-contrastivity type of issues such as countability-related pairs obresti (pl.) - interest (sg.) and pižama (sg.) - pajamas/pyjamas (pl), and false friends such as eventualen (EN possible, potential), problematika (EN problems, issues, topic), monden (EN fashionable).

(2) those introducing more general language issues and concepts of contrastive significance, i.e. topic-type linguistic entries such as false friends / lažni prijatelji, prepositions/predlogi, countability/stevnost, collocations/sopojavljanke, comma use/vejica (raba). These entries offer simple definitions and provide abundant exemplification, always in both languages and usually given as translated examples of use. Some add brief encyclopedic information.

More specifically, the entries listed under both (1) and (2) above are to be constructed, characterized, labelled, and classified primarily in terms of whether they 
- begin with the entry word(s) either in English (EN), in Slovene (SI), or in both languages (EN\&SI)

- are phrased as questions (Q)

- are of the non-specific (NSC) or specific contrastivity (SC) type

- contain definitions (DEF) and encyclopedic (ENC) information

- are topic-type linguistic entries (TOPIC)

- include information largely or solely in one language only, whether English (L2) or Slovene (L1)

- provide exemplification (EX)

- only hint at solutions to language problems or challenge the user to find them themselves (QUIZ)

- include quotations (QUOTE)

- contain links, references or cross-references (L/R/C-R).

The evaluation and discussion of the relative significance and appropriateness of the ten entry features listed and labelled above is a topic that clearly calls for another paper. Let me merely note at this point that there is nothing final about the ten features - they may well be subject to revision once the dictionary starts expanding and diversifying.

What follows is a small but varied selection of 20 alphabetized entries that can be profitably examined provided the reader is fluent in both Slovene and English. What they illustrate is, first, the actual microstructure in the subcategories of the above two basic types, and second, the presence or absence of the ten major features listed in the preceding paragraph:

advice in advise sta si oblikovno in pomensko blizu, a se razlikujeta glede na besedno vrsto: advice je nešteven - obstaja le $\mathrm{v}$ edninski obliki - samostalnik $\mathrm{s}$ pomenom 'nasvet(i)', advise pa je glagol s pomenom 'svetovati'. [confusables]

arrive - - at/in (pogosta napaka: arrive * to): n.pr. prispeti v New York - to arrive in New York [common error]

aspect / respect. Pogosta napaka mešanja dveh podobnih, a različnih samostalniških besed, ki je značilna za nematerne govorce: n.pr. SI $v$ tem oziru - EN in this respect in ne in this *aspect. Soroden problem opažamo n.pr. pri rabi pogostih stalnih angleških zvez in regard to, with regard to, as regards, ki vse pomenijo 'kar se tiče', pogosto napako nematernih govorcev * in regards pa interpretiramo kot težavo, ki izvira iz angleščine, namreč mešanje treh podobnih oblik te zveze $\mathrm{v}$ napačno. Torej ta problem ni nujno "slovenski«, ampak je kontrastivno nespecifičen. [confusables]

BESEDNE DRUŽINE [EN word families]: Some are very easy, others much more demanding (e.g. nutrition includes not only the adjective nutritious and the noun nutritionist but also the noun nutriment, noun/adjective nutrient, and the adjectives nutritional and nutritive). They can be useful in translating, for instance art texts: exhibit (not only SI 'razstavljati' but also 'eksponat' and in AmE also 'razstava'), exhibition ('razstava'), exhibitor ('razstavljalec'). The contrastive aspect is often significant, 
especially in the case of (very) similar forms across languages, as in SI revolucionar, revolucionaren vs. EN revolutionary (adj./n.!); EN kiropraktika, kiropraktik vs. EN chiropractic, chiropractor. And what about SI

- melanholija, melanholik, melanholičen or

- investicija, investicijski, investirati, investitor, or more technically

- kataliza, katalizirati, katalizator, katalitski/katalitičen

- do you really know their EN equivalents? [topic entry plus testing the user's knowledge]

besides and beside are NOT the same. Check the brief usage note at https://www. ldoceonline.com/dictionary/beside. [confusables]

COMMA usage / raba vejice: Najvažnejši kontrastivni nasvet je, da v EN pred veznikom that (SI da) nikoli ni vejice, v SI pa vedno, n.pr. Rekel je, da je utrujen. - He said that he was tired.

- Dober krajši spletni uvod v problematiko pravilne rabe ločil v angleškem jeziku: Nordquist 2020a. [topic entry and a reference source]

"CONFUSABLES": Gre za problem angleških besed, pogosto parov, ki jih lahko zamešamo, ker so si glede na pisavo in/ali izgovarjavo zelo podobne, $v$ resnici pa imajo (popolnoma, zelo ali delno) različne pomene, kolokacijske povezave in/ali slovnične lastnosti, n.pr. accept in except, adapt in adopt, admission in admittance, affect in effect, allusion in illusion, advice in advise, affect in effect, biannual in biennial, capital in capitol, complement(ary) in compliment(ary), conscious in conscience, deduce in deduct, dependence in dependency, deprived in depraved, discreet in discrete, disinterested in uninterested, distinct in distinctive, dominance in domination, emergence in emergency, entry in entrance, intend in intent, lend in loan, lie in lay, literal, literally, literary in literate, lose in loose, lie in lay, pair in pear, precede in proceed, prescribe in proscribe, principal in principle, rely in relay, rise in raise, than in then, sensual in sensuous, than in then, troubling in troubled, urban in urbane, itd. Včasih so take besede lahko (skoraj) sopomenske, n.pr. misinformation in disinformation ter flammable in inflammable, včasih pa sploh ne, n.pr. accept in except ali than in then (prim. Nordquist 2020b in Beare 2018b). [topic entry and two reference sources]

KOMENTAR: Here is Michael Quinion on the subject, reporting in 2011 on his World Wide Words website [http://worldwidewords.org/nl/diao.htm]:

English is rife with words that are confusingly similar. Some are spelled differently but have the same sound (homophones): break/brake, heallheel, cereal/serial; others are spelled the same but pronounced differently (homographs), such as entrance, invalid, moped, or wound. A third set (homonyms) combine the similarities: they are said and spelled the same, but have different meanings: bear, distemper, founder, plain, saw, tender. Some others are very close in form but have significantly different meanings, such as evoke, invoke, provoke. 
Native speakers are so used to them that we aren't in the least bothered that rest can mean both repose and remainder, that a bank may be both a financial institution and a place where the wild thyme blows, or that - lacking context - spring might refer to a jump, rivulet or season. Whole dictionaries have been dedicated to resolving confusions between such words for learners of English as a second language.

One reason why we have so many homonyms is that English is a mongrel language that has imported words from many sources, sometimes more than once, and has frequently modified them to generate new senses. Its utter lack of purity is well expressed as follows:

The result is that sets of homonyms rarely have a common source. An exception is the common senses of rap - a quick blow, a knocking sound, a type of popular music, talk or gossip, a commendation, a rebuke, a criminal charge - which all do seem to derive from the idea of a tap or blow. [encyclopedic topical treatment]

congenial vs. congenital - a good case of a pair of confusing words with widely different meanings. EN congenial-SI prijeten; primeren vs. EN congenital-SI prirojen! Example: congenial atmosphere - prijetno vzdušje; a congenital defect-prirojena okvara. [confusables]

interested ('zainteresiran') vs. interesting ('zanimiv'): I'm interested in books that are interesting to me. - Zainteresiran sem za knjige, ki so mi zanimive. [confusables plus prepositional issues]

LASTNA IMENA [EN proper names]: $\mathrm{V}$ današnjem času občasno naletimo na "čudne" ali vsaj nenavadne prevode zemljepisnih imen, pogosto pod vplivom angleških oblik: Primeri v SI so n.pr. Moldova, Laplandija in Angleski kanal (EN Moldova, Lapland, the English Channel) namesto pravilnih slovenskih oblik Moldavija, Laponska in Rokavski preliv. Na takšno prakso včasih naletimo tudi pri nekaterih drugih lastnih imenih, npr. EN Kremlin (to je še en primer v standardni slovenščini neobstoječe angleške - oblike) namesto pravilnega SI Kremelj. [topic entry]

najstnik, -ica - zanimiv, toda redko izpostavljen medjezikovni problem, saj je v tem primeru EN teenager le delna ustreznica: SI samostalnik se namreč nanaša na starost 11 - 19 let, EN pa na 13 - 19 let! Kako bomo torej v angleščino prevedli SI najstnik, kadar gre za starost 11 ali 12 let?? Odgovor: an 11-year-old, a 12-year-old. [unexpected interlingual relation]

PREDLOGI [EN prepositions] - Izbrani primeri izpričanih značilnih "slovenskih" predložnih napak pri prevajanju iz slovenščine v angleščino (napačni prevodi predlogov so označeni z zvezdico):

na koncertu - ${ }^{*}$ on / at a concert

na trgu - *on / in a square

PAZITE!

alergičen na-allergic *on (to) 
hvaliti se z necim - to pride oneself * with (on) something

nanašati se na - to apply * for (to)

odlociti se $z a$ - to decide *for (on)

ostati na večerji-stay ${ }^{*}$ on (for) dinner

ponosen na-proud ${ }^{*}$ on (of)

rešitev za (problem) - solution *for (to) a problem

vplivati na - to influence *on (Ø - nobenega predloga!)

zainteresiran $z a-$ interested ${ }^{*}$ for (in)

značilen $z a-$ typical *for (of)

KOMPLEKSNEJŠI PROBLEM: na postaji - *on latlin a station - toda ne kot sopomenki! Prim.: I want to get off at the next station. - Is there a waiting room in the station?

(Fox and Combley 2014, 1791) [topic entry with abundant exemplification]

PRETVORBA ENOT [EN conversions of units]: Tu gre predvsem za probleme, povezane $\mathrm{z}$ upoštevanjem različnih merskih enot - utežnih, dolžinskih in votlih - $\mathrm{v}$ slovenščini in angleščini. Ali n.pr. vemo ali vsaj znamo poiskati, kakšna je velikost Slovenije, izražena ne v kvadratnih kilometrih, ampak v kvadratnih miljah? Pa še nekaj: kako se to $\mathrm{v}$ angleščini zapiše? Pri tem se pojavijo včasih tudi razlike med britansko in ameriško rabo: $n$.pr. britanska utežna enota stone $(6,35 \mathrm{~kg})$ je neznana $\mathrm{v}$ ameriški rabi, galona pa sicer obstaja v obeh, a ni enaka - ameriška je namreč skoraj $20 \%$ manjša (AmE 3,79 l, BrE 4,55 l)! Pri navajanju n.pr. porabe goriva moramo upoštevati ne le pravilno pretvorbo milj $\mathrm{v}$ kilometre in galon $\mathrm{v}$ litre, temveč tudi drugačen splošni vzorec: v SI govorimo o »litrih na $100 \mathrm{~km}$ «, v EN pa o "prevoženih miljah na galono" (EN to do _ miles per gallon [N.pr. the car does about 40 miles per gallon). Prim. UnitConverters.net. (https://www.unitconverters.net/2 [topic entry with encyclopedic explanations]

Slovenia - Slovene ali Slovenian? V angleščini imamo pri prevodu pridevnika slovenski dve možnosti. Zato bodo vsaj nekateri uporabniki veseli citata iz znanega angleškega slovarja jezikovne rabe: "An inhabitant of the country in south central Europe is a Slovene; the derived adjective is Slovenian. The capital is Ljubljana." (Todd 1997, 382) [quotation-type issue and the solution]

SOPOJAVLJANKA ali kolokacija [EN collocation]: $S$ tem izrazom označujemo pogoste besedne zveze z neprenesenim pomenom, ki se med jeziki neredko razlikujejo na nepredvidljiv način glede ubeseditve oz. omejitev pri združljivosti, n.pr.

SI imeti predavanje - EN to give a lecture,

SI močan dež - EN heavy rain,

SI trdovraten kašelj in trdovraten madež- EN persistent cough in stubborn stain.

škorpijon - obstajata DVA prevoda v EN, in sicer s pomenskim razločkom: žival je scorpion, znak v horoskopu pa Scorpio. [interlingual non-congruence: divergent polysemy] 
ŠTEVNOST [EN countability]: Nekateri samostalniki $\mathrm{v}$ slovenščini in njihove ustreznice v angleščini se ločijo glede na slovnično lastnost števnosti. Števni samostalniki imajo tudi množino, neštevni pa praviloma ne - torej imajo le edninsko obliko. Primeri takšnih razlik so n.pr.: information - informacijal-je, advice - nasvet--ti, election(s) volitve, evidence - dokazl-zi, interest - obresti, pyjamas ali pajamas - pižama, real estate - nepremičninal-ne, unrest - nemir(i), turbulence - turbulencal-ce (v angl. je vedno možna le ednina); door/doors - vrata. Vendar pa je v angleščini po potrebi pluralnost pri neštevnih samostalnikih pogosto možno izraziti z zvezo samostalnik + of, n. pr. nasvet - a piece of advice. (prim. npr. Beare 2018a)

Dodatna težava je lahko tudi to, da neštevnost in števnost lahko včasih pri isti besedi $\mathrm{v}$ angleškem jeziku povzročita tudi spremembo pomena, n.pr. samostalnik liberty (nešteven, le edninska oblika) pomeni 'svoboda', liberties (števen, le množinska oblika) pa 'svoboščine.' [topic entry with abundant exemplification]

teden: Angleški prevod te samostalniške besede je seveda week. Kaj je torej razlog za to geslo? To je manj znano dejstvo, da je v britanski rabi teden obdobje od ponedeljka do nedelje, v ameriški angleščini pa od nedelje do sobote. To dejstvo kar v definiciji prvega pomena navajajo tudi nekateri učni slovarji angleščine - n.pr. Longman Dictionary of Contemporary English v tiskani verziji (Fox in Combley 2014, 2067) ali v spletni verziji na https://www.ldoceonline.com/dictionary/week. [unexpected encyclopedic difference between American and British English - non-specific contrastivity]

weight ali weigh? Obe besedi sta lahko pravilna izbira, toda prva (weight) je samostalnik s pomenom 'težà', druga (weigh) pa je glagol s pomenom 'tehtati'. [confusables]

ZANIKANJE [EN negation]: $\mathrm{V}$ zborni slovenščini - $\mathrm{v}$ nasprotju $\mathrm{z}$ angleščino - lahko rabimo več nikalnih oblik $\mathrm{v}$ istem stavku, $\mathrm{v}$ standardni angleščini pa le eno (pri prvi možnosti za zanikanje v stavku), n.pr. Nikoli mi ni ničesar povedal. - EN He has never told me anything. Med specifičnimi kontrastivnimi problemi naj omenimo predvsem zanikanje tipa tudi ne / tudi ni, kjer je standardni EN prevod not ... either (in ne *also not), n.pr. Tudi tam ga ni. - He is not there either.| Prav takó je ni v kubinji. - She is not in the kitchen either. [topic entry]

\section{Conclusion}

Again, as it turns out, there are virtually no bilingual usage dictionaries of any language pair in existence, which is why we need to know a lot more not only about the principles underlying the creation of such a reference work but also, more broadly, about its nature and rationale; moreover, it is likewise essential to look into how users of such a work go about using it and why and when, and into who exactly is likely to need it and consult it on a regular basis. Sensitivity to both user language-reference needs and user responses to queries as well as entry and entry-format testing should therefore be a desideratum to be kept in mind at all times.

A useful and user-friendly bilingual usage dictionary, and in the framework of this paper specifically one with English as an L2 and Slovene as an L1, must be based on clear principles that try to, first, make the most of the existing monolingual-type English usage dictionaries, 
particularly the EFL variety; and second, draw extensively on, one, foreign-language teachers' and translators' notes, findings, ideas and observations stemming from their own (practical) language work, and two, the existing empirical work resulting from largely corpus-based contrastive research involving both languages in question, that is, English as an L2 and Slovene as an L1.

\section{References}

Aarts, Bas, Sylvia Chalker, and Edmund S.C. Weiner. 2014. The Oxford Dictionary of English Grammar, 2nd ed. Oxford: Oxford University Press.

Algeo, John. 1991. "Sweet Are the Usages of Diversity." Word 42 (1): 1-17. https://doi.org/10.1080 /00437956.1991.11435829.

Allen, Robert E. 2009. “Dictionaries of Usage." In The Oxford History of English Lexicography, Volume II: Specialized Dictionaries, edited by Anthony P. Cowie, 339-60. Oxford: Clarendon Press.

Beare, Kenneth. 2018a. "Countable and Uncountable Nouns: The Basics." ThoughtCo.com. https://www .thoughtco.com/countable-and-uncountable-nouns-1210697?utm_campaign=grammartip\&utm _medium $=$ email\&utm_source $=c n \_n l \& u t m \_c o n t e n t=16516592 \& u t m \_t e r m=$.

—. 2018b. "Commonly Confused Word Pairs for ESL Learners." ThoughtCo.com. https://www .thoughtco.com/commonly-confused-word-pairs-p2-1209091.

Brians, Paul. (2004) 2013. "Common Errors in English." Washington State University, The Web Site of Professor Paul Brians. https://brians.wsu.edu/common-errors/. [Also a printed book: Brians, Paul. [2004] 2013. Common Errors in English Usage, 3rd ed. Wilsonville, OR: William, James \& Co.]

Brown, Keith, and Jim Miller. 2013. The Cambridge Dictionary of Linguistics. Cambridge: Cambridge University Press.

Butterfield, Jeremy, ed. 2015. Fowler's Dictionary of Modern English Usage, 4th ed. Oxford: Oxford University Press.

Collins. 2020a. "Browse all Official Collins Dictionaries." https://www.collinsdictionary.com/browse/.

—. 2020b. "Browse the English Usage." https://grammar.collinsdictionary.com/browse/english-usage/.

Fowler, Henry Watson. 1926. Modern English Usage. Oxford: Oxford University Press.

Fox, Chris, and Rosalind Combley, eds. 2014. Longman Dictionary of Contemporary English, 6th ed. Harlow, Essex: Pearson Education. https://www.ldocelonline.com.

Garner, Bryan A. 2016. Garner's Modern English Usage. Rev. 4th ed. of Garner's Modern American Usage. New York: Oxford University Press.

Garner, Bryan A., and Robert L. Greene. 2012. "Which Language and Grammar Rules to Flout." The New York Times, September 27, 2012. https://www.nytimes.com/roomfordebate/2012/09/27/which -language-and-grammar-rules-to-flout.

Garrett, Peter. 2010. Attitudes to Language. Key Concepts in Sociolinguistics. Cambridge: Cambridge University Press.

Gilman, E. Ward, ed. 1989. Webster's Dictionary of English Usage. A Merriam-Webster. Springfield, MA: Merriam-Webster.

Gómez González, María de los Ángeles, J. Lachlan Mackenzie, and Elsa M. González Álvarez, eds. 2008. Current Trends in Contrastive Linguistics. Studies in Functional and Structural Linguistics, Vol. 60. Amsterdam: John Benjamins Publishing.

Granger, Sylviane. 2015. “Contrastive Interlanguage Analysis: A Reappraisal.” International Journal of Learner Corpus Research 1 (1): 7-24. https://doi.org/10.1075/ijlcr.1.1.01gra.

Hands, Penny, ed. 2019. Collins COBUILD English Usage, 4th ed. Glasgow: Collins/HarperCollins Publishers.

Hartmann, R.R.K., and Gregory James. 1998. Dictionary of Lexicography. London and New York: Routledge.

James, Carl. 1980. Contrastive Analysis. Rptd. with corrections 1983. Harlow, Essex: Longman Group.

Longman. n.d. "Longman Dictionary of Contemporary English Online." https://www.ldoceonline.com/. 
McIntosh, Colin, ed. 2013. Cambridge Advanced Learner's Dictionary, 4th ed. Cambridge: Cambridge University Press.

Merriam-Webster. 2020. "Merriam-Webster Learner's Dictionary." https://learnersdictionary.com/.

Meyer, Charles F. 1993. "Investigating Disputed Usages." In Language Variation in North American English: Research and Teaching, edited by A. Wayne Glowka and Donald M. Lance, 302-12. New York: Modern Language Association of America.

Nordquist, Richard. 2020a. "An Introduction to Punctuation.” ThoughtCo. https://www.thoughtco.com /punctuation-definition-1691702.

—. 2020b. "Glossary of Usage: Index of Commonly Confused Words." ThoughtCo. https://www .thoughtco.com/commonly-confused-words-s2-1692693.

Partridge, Eric H. (1942) 1999. Usage and Abusage: A Guide to Good English, 3rd ed. Edited by Janet Whitcut. London: Penguin Books.

Punctuation Guide, The. 2011-2020. https:/www.thepunctuationguide.com/.

Schwarz, C.M., and M.A. Seaton, eds. 1985. Chambers Concise Usage Dictionary. [Edinburgh:] W \& R Chambers.

Sinclair, John McH., ed. 1992. Collins COBUILD English Usage for Learners. Glasgow: HarperCollins Publishers.

Stein, Gabriele. 2013. A Usage Dictionary English-German / German-English. Berlin: Walter de Gruyter.

Swan, Michael. (1980) 2016. Practical English Usage, 4th ed. Oxford: Oxford University Press. [4th ed. abandons the $\mathrm{A}-\mathrm{Z}$ format in favor of a thematic arrangement]

Todd, Loreto. 1997. The Cassell Dictionary of English Usage. London: Cassell.

Trask, Robert Lawrence. 2001. Mind the Gaffe: The Penguin Guide to Common Errors in English. London: Penguin Group/Penguin Books.

Turton, Nigel D., and John Brian Heaton. 1996. Longman Dictionary of Common Errors, 2nd ed. Harlow, Essex: Addison Wesley Longman. 